\title{
Modeling Prices of Islamic Commodity Swaption
}

\author{
Nahla Ghazi Aljudaibi, Shabir Hakim and Tahar Tayachi \\ Effat University, Jeddah, Saudi Arabia
}

\begin{abstract}
Derivatives that manage commodity risk over multiple periods are not Sharī 'ah-compliant. This study proposes a Sharī'ah-compliant swaption model (wa'dān or two promises on swap) for hedging commodity risk. The model combines two separate and independent wa'ds (wa'dān) on commodity swap through murābahah contract. Black (1976) model is used to determine the intrinsic value for the counter-parties involved in the contract. The risk-free rate is replaced with the return on AAA șukūk to make Black (1976) model Sharì'ah compliant. The proposed Shari 'ah-compliant model is compared with the conventional swaption model, and with the Islamic commodity option (wa'dān on commodity) for its effectiveness. The tests of the model show that the proposed Islamic pricing model has a higher positive effect than the conventional swaption model. In addition, the proposed Islamic commodity swaption is more efficient than Islamic commodity options. The reliability of the proposed model was established by the Monte Carlo simulation run with 10,000 iterations.
\end{abstract}

Keywords: Islamic hedging, Pricing, Islamic commodity Swaption, Wa'dān on commodity swap.

KAUJIE Classification: K1, K14, L31 


\section{Introduction}

The lack of Islamic hedging and the limited amount of available literature on pricing Islamic derivatives is an issue that the current study tries to solve. We do this by creating, evaluating and pricing a fair model. We propose the Islamic commodity swaption model, WCS (Wa'dān on Commodity Swap), to determine the intrinsic value in hedging risk. We also utilize the modified Black (1976) model to evaluate WCS regarding parties' returns and measure the profitability of WCS over the Islamic commodity option, WCO (Wa'dān on Commodity Option). The study tries to address three research questions.

(a) What is the intrinsic value in the fair Islamic commodity swaption using wa'dān for hedging risk?

(b) What is the value of the WCS regarding parties' returns?

(c) How much is the profitability for using WCS over the WCO regarding parties' return?

To answer these questions the study proposes an innovative Islamic product called wa'dān on commodity swap (WCS). The International Islamic Financial Market (IIFM) has developed Islamic Foreign Exchange Product Standards based on wa'dān - two separate and independent $w a ' d s$ - for both the seller and the buyer. It is a hybrid product for commodity hedging combining two separate wa' $d s$ for swap through murābahah contract. Also, we develop an Islamic pricing commodity swaption model for pricing WCS (which does not have a price in the market) by modifying Black (1976) model to be Sharīah-compliant. Furthermore, we study the effectiveness of this model of hedging the two parties (the seller and the buyer) from potential risk in comparison with the normal wa'dān on commodity option (WCO).

The hedging commodity model in this study provides fairness for the users, buyer and seller, because both sides can exercise their promise and hedge. This will satisfy the Islamic scholars who claim that $w a^{\prime} d$ is not a fair contract due the loss that can occur to the counterparty if the holder exercises his promise.

We aspire, through this study, to enrich the Islamic finance literature and inspire scholars to explore this new product.
The rest of the paper is organized as follows: section 2 summarizes the literature review; the data and methodology is presented in section 3 in which we discuss the data and research design which clarifies the study's method for answering the three research questions. The findings and discussion of the results is given in section 4 while section 5 concludes the paper.

\section{Literature review}

Islamic finance is a rapidly growing market with Islamic scholars constantly trying to find new and innovative Islamic instruments and techniques to keep pace with the rapid growth of the economy. This innovative drive gained special significance after the 2008 financial crises. Hedging, which is important for protection and saving purposes, is one area in which Islamic finance scholars need to improve upon. It may be noted here that in 2006 IIFM has taken the lead to identify the need for hedging in Islamic finance and is the pioneer in this important risk mitigation segment.

$W a^{\prime} d$ is a risk mitigation technique utilized by Islamic financial institutions to prevent the risk of price fluctuation, interest risk, foreign exchange risk, etc. For example, it is used in an innovative product proposed by Kok, Giorgioni, and Laws (2014, p. 246) for hedging commodity price risk through murābahah contract. The model proposed in this study takes its inspiration from their work. $W a^{\prime} d$ can be a contract to hedge against currency risk and Islamic swap which happen in many contracts like murābahah, tawarruq and bay' al-inah. Ayub (2011, p. 13) defined the wa ' $d$ based Islamic swap as an agreement between two parties to enter wa'd through murābahah contract; primary murābahah and reverse muräbahah which is more commonly known as tawarruq or more correctly 'organized' tawarruq. This study is an attempt to explain how the hybrid structure of two unilateral wa'ds (wa'dān) for commodity swap through murābahah works.

Regarding the pricing of wa'd through murābahah contract, the authors could not find any research which discusses the pricing model of wa'd with real data or even without real data except one paper by Aboulaich and Dchieche (2015). They suggest pricing wa'd bil murābahah by adopting Black and 
Scholes (1973) model and adjusting it to comply with Sharī'ah laws. They use the European call option and adjust the Black and Scholes model by replacing the interest rate with the rate of return (R) derived from the model.

$$
\text { They found } R=1 \backslash t \sqrt{\frac{p}{\left.S_{0}\left(1-N d_{1}\right)\right)+p e^{-r t} N\left(d_{2}\right)}}-1
$$

where $\mathrm{N}(\mathrm{d} 1)$ and $\mathrm{N}(\mathrm{d} 2)$ are the cumulative standard normal distribution functions, $\mathrm{R}$ is the rate of return, $e^{-r t}$ is the discount rate, $\mathrm{p}$ is the price at time $\mathrm{T}$, and $\mathrm{S}_{0}$ is the spot price (Aboulaich \& Dchieche, 2015, pp. 529-531).

Wa 'dān has recently caught the scholar's attention in the Islamic financial engineering industry in recent years. It is being used to develop Islamic finance products competitive with the derivatives used in conventional finance. $A l$-wa 'dān has been defined by many Islamic scholars in many research papers. For instance, Aznan Hasan (2008) describes the concept of wa'dān. He clarifies that wa'dān refers to two promises (wa'ds) made by the parties involved in a particular business transaction. These two promises are given unilaterally by one party to another and vice versa, where they are unrelated to each other and their respective fulfillment depends on two independent conditions (Hasan, 2008, p. 31).

Wa 'dān has two important characteristics:

(a) The promises are independent from each other.

(b) Their application depends on two different conditions (Muhammad, Yaacob, \& Hasan, 2011, p. 31, Abdullah \& Abdul Rahman, 2015, p. 130).

The Islamic Fiqh Academy allows Islamic researchers and scholars to improve the option contract using wa'd and 'urbūn (deposit). Muhammad Elgari has suggested some restrictions in these contracts to avoid the gambling elements:

1) The institution must deal with the real owner of the stock.

2) Only European style option is exercised, which is exercised at maturity date to reduce the exposure for price fluctuation.

3) The option will expire at the beginning of the first hour in the last day of the contract to avoid the rise of price because of demand increase (Bashir, 2016, p. 10).
Wa 'dān is not very widely utilized in Islamic finance due to the debate surrounding the permissibility of this kind of product in many research papers. it is usually used as a hedging instrument for Islamic capital markets. Some Islamic scholars argue that they consider wa' $d \bar{a} n$ contract as more just and fair than the simple wa'd contract because in wa'dōn contract, the two parties can exercise their promises and protect their position. A survey conducted through a questionnaire in Malaysia by the Malaysia Islamic bank 2008, revealed that wa'd mulzim is widely used. The researcher surveyed the possibility of Malaysia Islamic bank adopting wa'dān to protect both parties. The result showed great interest in using wa'dān (Hasan, 2008, p. 52). A good example of wa'dān product is ijārah rental swap (IRS) contract, which is a hedging technique against ijärah floating finance. In this contract, the holder can swap the floating rate cash flow to fixed rate cash flow and vice versa. (Abdullah \& Abdul Rahman, 2015, p. 133)

There is no research that uses real data to calculate hedging payoff for two parties through real transaction. Although, some theoretical researches about wa' $d \bar{a} n$ have been published, yet they are not enough to form a strong base for further empirical research. Accordingly, this paper develops the null and alternative hypotheses as follows:

$\mathrm{H} 1_{0}=$ this model offers no intrinsic value in hedging risk for a fair Islamic commodity swaption using wa'dān.

$\mathrm{H}_{\mathrm{a}}=$ this model offers intrinsic value in hedging risk for a fair Islamic commodity swaption using wa'dān.

The International Swaps and Derivatives Association (ISDA, 2013, p. 22) considers commodity swaption as a series of forward contracts entered into a trade date $\left(T_{0}\right)$ with different settlement dates. The other party pays at maturity, if the holder exercises his right, the difference between the fixed price and the floating price in case of receiver swaption, or the difference between the floating price and the fixed price in case of payer swaption. There can be multiple settlement dates during the period. The payoff for the European commodity swaption of receiver swaption is calculated by:

$$
\mathrm{P}\left(\mathrm{T}_{0}\right)=\Sigma \mathrm{p}\left(\mathrm{T}_{0}, \mathrm{~T}_{\mathrm{i}}\right) * \max \left[\mathrm{X}\left(\mathrm{T}_{0}\right)-\mathrm{S}_{0}\right]
$$


And for payer swaption

$$
\mathrm{C}\left(\mathrm{T}_{0}\right)=\Sigma \mathrm{p}\left(\mathrm{T}_{0}, \mathrm{~T}_{\mathrm{i}}\right) * \max \left[\mathrm{S}_{0}-\mathrm{X}\left(\mathrm{T}_{0}\right)\right] .
$$

Black (1976) model is the standard market model to price swaptions, introduced by Fisher Black in 1976. It is an extension of the Black-Scholes model that is used to value the European swaption. To the best of our knowledge, there is no attempt of pricing the commodity swaption for European option. Most of the studies focus on pricing interest rate swaption. The present study focuses on pricing the Islamic crude oil swaption or wa 'dān on crude oil swap by paying (payer wa' $d$ on commodity swap) or receiving (receiver wa'd on commodity swap) a fixed price against the floating price of the underlying commodity. In order to develop the Black (1976) model to be more Shari'ah-complaint, the interest rate is substituted with the rate of return on triple A sukūk as done by Hakim, Hamid and Meera (2016, p. 26). They used the rate of return on triple A șukūk in CAPM model to calculate the return for Sharīahcomplaint stocks. Thus, this research can develop the second null and alternative hypotheses as follows:

$\mathrm{H} 2_{0}=$ There is no effect on the parties' return from the development of an Islamic pricing commodity swaption (WCS).

$\mathrm{H} 2_{\mathrm{a}}=$ There is an effect on the parties' return from the development of an Islamic pricing commodity swaption (WCS).

We calculate the pricing of (WCS) and (WCO) regarding parties return to provide this study with required data to justify choosing wa'dān on commodity swap over the wa'dān on commodity. Some argue that Islamic commodity swaption is no different than Islamic commodity option regarding the profitability for both parties. This study compares Islamic commodity swaption over Islamic commodity option. The proposed model (WCS) has several wa' $d$ exercises on commodity swap that have a positive effect for the two parties in case of profit, while in the wa'dān on a commodity (WCO) model, the parties can only exercise the wa' $d$ once on the maturity date. The available literature in the field of Islamic derivatives does not offer studies that test the difference in profitability between Islamic commodity swaption and Islamic commodity option. Therefore, this research provides a third null and alternative hypothesis as follows:
$\mathrm{H}_{0}$ : Islamic commodity swaption (WCS) offers the same profitability when using Islamic commodity option (WCO) for both parties.

$\mathrm{H}_{\mathrm{a}}$ : Islamic commodity swaption (WCS) offers more profitability than commodity options (WCO) for both parties.

\section{Data and Methodology}

This research will formulate a model of wa'dān on commodity swap through murābahah contract to hedge against fluctuating price risk by using Black (1976) model. The proposed model for this study is evaluated by calculating the intrinsic value by using Black (1976) model to answer the first research question (what is the intrinsic value in the fair Islamic commodity swaption (WCS) using wa'dān for hedging risk?). To answer the second question of this research (what is the value of the Islamic price commodity swaption (WCS) regarding parties' returns?), this study will compare the profit of both parties after applying Black (1976) model on both the rate of return (triple A sukūk) and LIBOR interest rate. Regarding the third question (how much is the profitability for using Islamic commodity swaption, WCS, over the Islamic commodity option, WCO, regarding parties' return?), we calculate the profit for normal $w a ' d_{1}$, put option, and $w a^{\prime} d_{2}$, call option, and compare it with the profit of receiver swap based on wa'd (receiver swaption), and payer swap based on wa'd (payer swaption). The Monte Carlo simulation is conducted in this study to test the reliability of the Shar'`ah-compliant Black (1976) results. The data used in this study is the time-series data of OPEC price crude oil and Arab light crude oil, obtained from the quandl website (https://www.quandl.com/ data/OPEC/ORB-OPEC-Crude-Oil-Price) and averaged for each two-month period starting from 2006 until 2016. Furthermore, time-series data on total return index of Dow Jones triple A rated sukūk is used as a substitute for interest rate in Black (1976) model. This is also averaged for each two-month period starting from 2006 until 2016. Additionally, LIBOR (The London Interbank Offer Rate) time series data, likewise, averaged for each two-month period starting from 2006 until 2016 is collected from Bloomberg database. Moreover, strike prices and variances will be calculated manually to be applied in the Black (1976) model and the Black \& Scholes (1973) model. 
Wa'dān on swap includes two separate wa'ds on swap, the receiver wa' $d$ on commodity swap and the payer $w a^{\prime} d$ on commodity swap. Each party has a promise to be exercised at the maturity date to swap a commodity with a fixed price $\mathrm{k}$, in case of receiver wa'd on swap, or swap the fixed price $\mathrm{k}$ with a commodity in case of payer wa' $d$ on swap. This contract lasts for $t$ years starting at year $\mathrm{T}$. However, in the model proposed in this study, the contract lasts for one year with six two-month periods. There are $\mathrm{m}$ payments per year under the swap. The Black model for receiver and payer swaption (receiver and payer wa ' $d$ based on swap) is:

$$
\begin{aligned}
& \mathrm{S}_{\text {payer }}=\sum_{i=1}^{M n} p\left(0, T_{i}\right)\left[S_{0} N\left(d_{1}\right)-S_{k} N\left(d_{2}\right)\right. \\
& d_{1}=\frac{\ln \frac{s_{0}}{s_{k}}+\left(r_{f}+\sigma^{2} / 2 T\right)}{\sigma \sqrt{T}} \\
& d_{2}=d_{1}-\sigma \sqrt{\mathrm{T}} \\
& \mathrm{S}_{\text {receiver }}=\sum_{i=1}^{M n} p\left(0, T_{i}\right)\left[S_{K} N\left(d_{2}\right)-S_{0} N\left(d_{1}\right)\right] \\
& \tau=\text { Tenure of swap in years. } \\
& \mathrm{S}=\text { Spot price of the underlying commodity. } \\
& \mathrm{K}=\text { Strike price of the swap based on wa' } d \\
& \mathrm{r}=\text { rate of return on triple A suk } u \bar{u} k \\
& \mathrm{~T}=\text { Time to expiration in years or months } \\
& \sigma=\text { Volatility of the forward-starting swap price. } \\
& \mathrm{m}=\text { Compounding per year in swap price }
\end{aligned}
$$

Figure (1) The Proposed Model of The Study



The designations of the parties in the structure above are as follows:

Party 1, receiver swap, is the seller of crude oil. Party 2, payer, is the buyer of crude oil. Party 3, is the third-party dealer, (OTC NYMEX), exercising $w a^{\prime} d_{1}$ on commodity swap (seller) and $w a^{\prime} d_{2}$ on commodity swap (buyer).

\section{Mechanism of the model}

Party 1 (seller of crude oil) enters into an agreement with the buyer to sell the crude oil through murābahah contract. Both parties, the buyer and the seller, are fearful of a fluctuation in prices and wish to protect themselves within this hybrid product. Party 1 (seller of crude oil) and party 2 (buyer of crude oil) agree to engage in murābahah contract through a dealer by purchasing, premium, two independent $w a^{\prime} d s$; $w a^{\prime} d_{l}$ for receiver commodity swap and $w a ' d_{2}$ for payer commodity swap in OTC (over-the-counter) market. This wa'd swaps the market price of the commodity with a fixed price from the seller or the buyer by the dealer at maturity date. The dealer pays the difference for both parties to hedge their position. Strike price for the swap based on wa'dān contract is always ATM (At the money) and fixed for both counterparty. 
Receiver $w a^{\prime} d$ on commodity swap $\left(w a^{\prime} d_{l}\right)$ : is a promise from seller to dealer to sell or swap the crude oil at market price if the dealer hedges his position and pays the difference in case the market price is lower than the strike price at the maturity date.

Payer wa'd on commodity swap ( $\left.w a^{\prime} d_{2}\right)$ : is a promise from buyer to dealer to buy or swap the crude oil at market price if the dealer hedges his position and pays the difference if market price is higher than the strike price at the maturity date.

This hybrid product is set up between party 1 and party 2 through party 3 whereby it is a series of murābahah linked with wa'dān on commodity swap contract entered at trade date $\left(\mathrm{T}_{0}\right)$ with different settlement dates (every two months). Party 1 (receiver $w a ' d$ on commodity swap), the seller, can exercise his promise and sell the crude oil to the buyer if the dealer pays the difference when the market price is lower than the strike price. Party 2 (payer $w a^{\prime} d$ on commodity swap), the buyer, exercises his wa' $d$ and pays his installment every 60 days $(\mathrm{q}+\mathrm{y})$ if the dealer pays the difference when the market price is higher than the strike price. Both the markups and the premium will be known (and set) at the same time $\mathrm{T}_{0}$. This product is exercised every 60 days for one-year swap. Pricing this product will need a modified Black (1976) model to be acceptable in Islamic finance.

\section{Payoffs for each of the parties:}

Summary of symbols:

$\mathrm{B}_{1}$ : premium for $w a{ }^{\prime} d_{1}$ on commodity swap and $w a ' d_{2}$ on commodity swap

$\mathrm{S}_{1}$ : spot price at time $\mathrm{T}_{0}$

$\mathrm{S}_{2}$ : spot price at $\mathrm{T}_{1}$ (maturity date)

$\mathrm{X}_{1}$ : cost + markup price of muräbahah $\left(\mathrm{S}_{1}+\mathrm{y}\right)$

Y: profit percentage for murābahah contract

Q: exercise price of $w a^{\prime} d_{l}$ and $w a^{\prime} d_{2}$ which is the strike price at the money (ATM)

\section{Receiver swaption and payer swaption scenarios:}

Scenario 1: For $S_{2}<Q$, wa'd is exercised for party 1 and not exercised for party 2

At time $T_{0}$ : in all Scenarios

Party 1 pays premium to party $3=\beta_{1}$

Party 2 pays premium to party $3=\beta_{2}$

Party 3 earns $\beta_{1}+\beta_{2}$

At time $T_{1}$ : wa' $d$ is exercised for party 1 and not exercised for party 2

Party 1 sells or swap the commodity to party 2 at cost plus some markup, $\mathrm{x}(\mathrm{Q}+\mathrm{Y})$

After one year payoff of partyl is $\mathrm{P}\left(\mathrm{T}_{0}\right)=$ $\Sigma \mathrm{p}\left(\mathrm{T}_{0}, \mathrm{~T}_{\mathrm{i}}\right) * \max \left[(\mathrm{Q}+\mathrm{y})-\left(\mathrm{S}_{2}+\mathrm{y}\right) \mathrm{T}_{0}\right]$

Party 2 takes delivery of commodity and pays Party 1 $=\mathrm{x}\left(\mathrm{S}_{2}+\mathrm{Y}\right)$

Party 3 earns $\left(\beta_{1}-\left(\mathrm{Q}-\mathrm{S}_{2}\right)\right)+\beta_{2}$

Senario 2: for $S_{2}>Q$, wa'd is not exercised for party 1 but is exercised for party 2

Payoffs at time $T_{1}$ :

Party 1 sells or swaps the commodity to party 2 at cost plus some markup, $\mathrm{x}\left(\mathrm{S}_{2}+\mathrm{Y}\right)$ party 2 takes delivery of commodity and pays party $1=x(Q+Y)$

After one year payoff for party 2 is $C\left(\mathrm{~T}_{0}\right)=\Sigma \mathrm{p}$ $\left(\mathrm{T}_{0}, \mathrm{~T}_{\mathrm{i}}\right) * \max \left[\left(\mathrm{S}_{2}+\mathrm{Y}\right)-(\mathrm{Q}+\mathrm{Y})\left(\mathrm{T}_{0}\right)\right]$.

Party 3 earns $\beta_{1}+\left(\beta_{2}-\left(\mathrm{S}_{2}-\mathrm{Q}\right)\right)$

Table 1 below illustrates the model in different scenarios for each party. Notice that this structure is for a (receiver wa'd on commodity swap), (payer wa'd on commodity swap) and the dealer. 
Table (1) Payoffs for each of the parties

\begin{tabular}{|c|c|c|c|}
\hline & Party 1 & Party 2 & Party 3 \\
\hline At $T_{0}$ & pays premium to Party $3=\beta_{1}$ & $\begin{array}{l}\text { pays premium to } \\
\text { Party } 3=\beta_{2}\end{array}$ & earns $\beta_{1}+\beta_{2}$ \\
\hline $\begin{array}{l}\text { At } \mathrm{T}_{1} \text { For } \mathrm{S}_{2}<\mathrm{Q}, w a^{\prime} d \text { is } \\
\text { exercised }\end{array}$ & $\begin{array}{l}\text { sells or swap the commodity } \\
\text { to Party } 2 \text { at cost plus some } \\
\text { mark-up, } x(Q+Y)\end{array}$ & $\begin{array}{l}\text { takes delivery of commodity } \\
\text { and pays Party } 1=x(Q+Y)\end{array}$ & earns $\left(\beta_{1}-\left(Q-S_{2}\right)\right)+\beta_{2}$ \\
\hline $\begin{array}{l}\text { For } \mathrm{S}_{2}>\mathrm{Q}, w a \text { 'd is not } \\
\text { exercised }\end{array}$ & $\begin{array}{l}\text { sells the commodity to the } \\
\text { market at cost plus some } \\
\text { mark-up, } x=\left(S_{2}+Y\right)\end{array}$ & $\begin{array}{l}\text { purchases commodity from } \\
\text { market at } x=\left(S_{2}+Y\right)\end{array}$ & earns $\beta_{1}+\left(\beta_{2}-\left(S_{2}-Q\right)\right)$ \\
\hline
\end{tabular}

Party 1 exercise his wa' $d$ and party 2 does not.

Party 2 exercise his wa' $d$ and party 1

Intrinsic value of the receiver $w a^{\prime} d$ on commodity swap after one year is given by:

$$
\mathrm{P}\left(\mathrm{T}_{0}\right)=\Sigma \mathrm{p}\left(\mathrm{T}_{0}, \mathrm{~T}_{\mathrm{i}}\right) * \max \left[(\mathrm{Q}+\mathrm{y})-\left(\mathrm{S}_{2}+\mathrm{y}\right) \mathrm{T}_{0}\right]
$$

Intrinsic value of the payer wa' $d$ on commodity swap after one year: $\mathrm{C}\left(\mathrm{T}_{0}\right)=\Sigma \mathrm{p}\left(\mathrm{T}_{0}, \mathrm{~T}_{\mathrm{i}}\right) * \max \left[\left(\mathrm{S}_{2}+\mathrm{Y}\right)\right.$ $\left.(\mathrm{Q}+\mathrm{Y})\left(\mathrm{T}_{0}\right)\right]$.

\section{Wa 'dān on Commodity (commodity options):}

Payoffs for each of the parties regarding parties' return:

Scenario 1: For $S_{2}<Q$, wa'd is exercised for party 1 and not exercised for party 2

At time $T_{0}$ : in all scenarios as well as wa'dān on commodity swap

Party 1 pays premium to party $3=\beta_{1}$

Party 2 pays premium to party $3=\beta_{2}$

Party 3 earns $\beta_{1}+\beta_{2}$

At time $T_{1}$ : wa'd is exercised for party 1 and not exercised for party 2

Party 1 sells the commodity to party 2 at cost plus some markup, $\mathrm{x}(\mathrm{Q}+\mathrm{Y})$
After one year payoff of party 1 is $\mathrm{P}\left(\mathrm{T}_{0}\right)=$ $\max \left[(\mathrm{Q}+\mathrm{y})-\left(\mathrm{S}_{2}+\mathrm{y}\right) \mathrm{T}_{0}\right]$

Party 2 takes delivery of commodity and pays Party $1=\mathrm{x}\left(\mathrm{S}_{2}+\mathrm{Y}\right)$

Party 3 earns $\left(\beta_{1}-\left(\mathrm{Q}-\mathrm{S}_{2}\right)\right)+\beta_{2}$

Senario2: for $S_{2}>Q$ wa'd is not exercised for party 1 but is exercised for party 2

Payoffs at time $T_{1}$ :

Party 1 sells the commodity to party 2 at cost plus some markup, $\mathrm{x}\left(\mathrm{S}_{2}+\mathrm{Y}\right)$ party 2 takes delivery of commodity and pays party $1=x(Q+Y)$

After one year payoff for party 2 is $\mathrm{C}\left(\mathrm{T}_{0}\right)=$ $\max \left[\left(\mathrm{S}_{2}+\mathrm{Y}\right)-(\mathrm{Q}+\mathrm{Y})\left(\mathrm{T}_{0}\right)\right]$.

Party 3 earns $\beta_{1}+\left(\beta_{2}-\left(S_{2}-Q\right)\right)$

\section{Findings and Discussions}

\subsection{Descriptive statistics}

The data examined are OPEC price, Dow Jones triple-A rated sukük total return index and LIBOR. The results are shown in Table 2.

Table (2) Descriptive statistics

\begin{tabular}{|l|c|c|c|c|c|c|c|c|}
\hline Data & $\mathbf{N}$ & Min & Max & Mean & Median & SD & Skew & Kurtosis \\
\hline OPEC price & 66 & 29.62 & 129.25 & 80.09 & 77.33 & 26.43 & -0.08 & -1.33 \\
\hline R.O.R triple A & 66 & -0.65 & 2.56 & 0.33 & 0.26 & 0.62 & 1.51 & 3 \\
\hline LIBOR & 66 & 0.15 & 28337 & 430.68 & 0.27 & 3487.88 & 7.76 & 59.09 \\
\hline
\end{tabular}

N: Number of the observation, Min: Minimum number of observations, Max: Maximum number of observations, SD: Standard Deviation, Skew: Skewness. 
Mean and median are the best way to represent the central tendency of the numerical data. The average of OPEC price and rate of return on triple A suku $u$ has an exactable average which is 80.9 for the oil price and 0.33 for the rate of return. The mean of LIBOR is misleading because of skewness. The skewness is due to few of the LIBOR rates being abnormally high, over 5 . This happened during the financial crisis in 2007 and 2008 which suffered from highly uncertain creditworthiness of financial institutions and most importantly subprime mortgages. This resulted in the lenders reducing the lending which caused an increase in demand for liquidity which in return affected the LIBOR interest rates. These large values tend to inflate the mean and make it unrepresentative of the majority of the interest rate. The median is the "middle" observation when the data is arranged for better representation of the central tendency. For LIBOR, this is 0.27 . The standard deviation (SD) represents the spread of the data around the mean. The SD for OPEC price and rate of return on triple A sukukk are 26.4 and 0.62 respectively which means the spread is not misleading and outliers data are not affecting the spread. The skew is symmetric for OPEC price and highly positively for rate of return on triple A suku $k$. Kurtosis for both is within acceptable range between $(-3,3)$. As mentioned earlier, the misleading skew, due to few of the LIBOR rates being abnormally high (over 5), affects the mean and makes it unrepresentative of most of the interest rates which consequently affects the standard deviation. Kurtosis is highly positively for LIBOR data.

\subsection{Hypotheses testing}

\section{First hypothesis}

This section tests the hypotheses presented in the literature review. We presented three hypotheses. The first one is about the intrinsic value of the proposed model.

The null hypothesis is:

$\mathrm{H} 1_{0}=$ this model offers no intrinsic value in hedging risk for a fair Islamic commodity swaption using wa'dān.

The alternative hypothesis is:

$\mathrm{H} 1_{\mathrm{a}}=$ this model offers intrinsic value in hedging risk for a fair Islamic commodity swaption using wa'dān.

Thus, the payoff model for an intrinsic value of the (receiver $w a{ }^{\prime} d$ on commodity swap) after one year is:

$$
\mathrm{P}\left(\mathrm{T}_{0}\right)=\sum \mathrm{p}\left(\mathrm{T}_{0}, \mathrm{~T}_{\mathrm{i}}\right) * \max \left[(\mathrm{Q}+\mathrm{y})-\left(\mathrm{S}_{2}+\mathrm{y}\right) \mathrm{T}_{0}\right]
$$

The intrinsic value of the (payer wa' $d$ on commodity swap) after one year:

$$
\mathrm{C}\left(\mathrm{T}_{0}\right)=\Sigma \mathrm{p}\left(\mathrm{T}_{0}, \mathrm{~T}_{\mathrm{i}}\right) * \max \left[\left(\mathrm{S}_{2}+\mathrm{Y}\right)-(\mathrm{Q}+\mathrm{Y})\left(\mathrm{T}_{0}\right)\right] .
$$

Table 3 and figure 2 show the results for the intrinsic value for both parties.

Table (3) The intrinsic value for receivers and payer wa' $d$ based on swap for the proposed model

\begin{tabular}{|c|c|c|c|}
\hline Date & $\begin{array}{c}\text { Intrinsic value for payer } \boldsymbol{w a} \boldsymbol{d} \\
\text { based on swap }\end{array}$ & Dif & $\begin{array}{c}\text { Intrinsic value for receiver } \boldsymbol{w a} \boldsymbol{d} \\
\text { based on swap }\end{array}$ \\
\hline 2016 & 15.215833 & 0.17 & 15.045 \\
\hline 2015 & 20.732 & 0 & 20.732 \\
\hline 2014 & 45.075 & 0.075 & 45 \\
\hline 2013 & 8.21 & 0.86 & 7.352 \\
\hline 2012 & 13.592433 & 0.1 & 13.4884 \\
\hline 2011 & 4.1001 & 0 & 4.0994 \\
\hline 2010 & 15.855 & 0 & 15.855 \\
\hline 2009 & 21.49 & 0 & 21.49 \\
\hline 2008 & 89.36332 & 0.166 & 89.1975 \\
\hline 2007 & 28.8866 & 2 & 26.87 \\
\hline 2006 & 12.545 & 0 & 12.545 \\
\hline
\end{tabular}

Note: dif is the difference between intrinsic value for payer $w a^{\prime} d$ based on swap and intrinsic value for receiver $w a{ }^{\prime} d$ based on swap; dif = payer - receiver, 


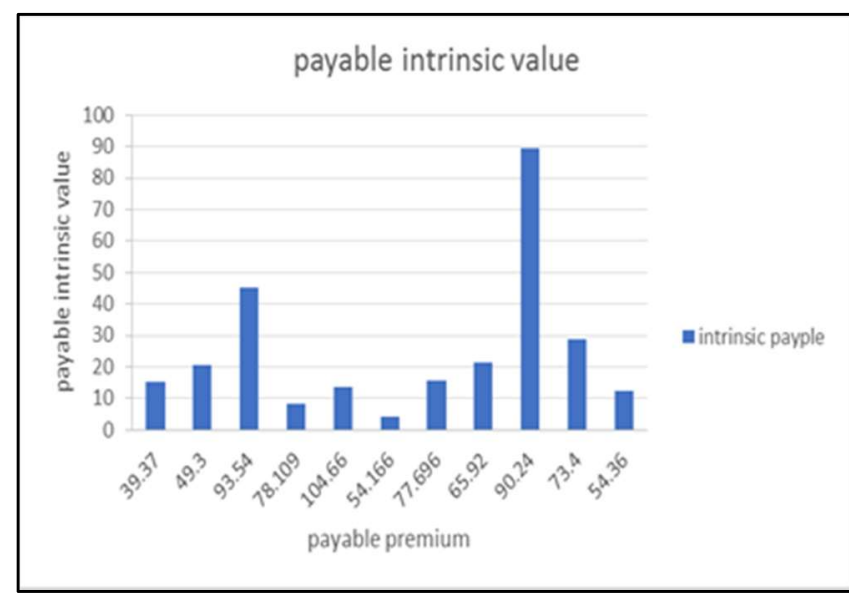

Figure (2.1) The payer intrinsic value



Figure (2.2) The receiver intrinsic value

Figure $2(1,2)$ The Receiver and Payer intrinsic value

The results above from the table and the figure showed that the proposed model has an intrinsic value due to the positive results that appear in the table 3 and the figure which means each party, the payer and receiver wa' $d$ on commodity swap, receives after one year a payoff that ranges between $\$ 7.352$ and $\$ 89.36332$. The difference of the payoff between the two parties represented in the figure showed both parties received similar payoffs which is ascertained by the difference in the table 3 which shows that the difference is between $\$ 0.1$ and $\$ 2$.

Therefore, the study must accept the alternative hypothesis and reject the null hypothesis. Hence, this model offers intrinsic value in hedging risk for a fair Islamic commodity swaption.

\section{Second hypothesis}

In our second hypothesis, the null hypothesis was:

$\mathrm{H} 2_{0}=$ There is no effect on the parties' return from the development of an Islamic pricing commodity swaption (WCS).
The alternative hypothesis was:

$\mathrm{H} 2_{\mathrm{a}}=$ There is an effect on the parties' return from the development of an Islamic pricing commodity swaption (WCS).

The study used RStudio for pricing the proposed model premium for both parties the receiver and payer wa' $d$ based on swap by applying the Islamic Black (1976) model, then pricing second time for conventional model by using LIBOR interest rate for risk-free rate to compare and measure the effectiveness of this proposed model regarding parties' profit. This is represented by the following formula for receiver and payer wa' $d$ passed on swap.

$$
\begin{aligned}
& \mathrm{S}_{\text {payer }}=\sum_{i=1}^{M n} p\left(0, T_{i}\right)\left[S_{0} N\left(d_{1}\right)-S_{k} N\left(d_{2}\right)\right] . \\
& \mathrm{S}_{\text {receiver }}=\sum_{i=1}^{M n} p\left(0, T_{i}\right)\left[S_{k} N\left(d_{2}\right)-S_{0} N\left(d_{1}\right)\right]
\end{aligned}
$$

The following tables illustrate the premium for both models, Islamic and conventional, which will be used for calculating the profits for each party. 
Table (4) The premium for Islamic and conventional proposed model for both parties

\begin{tabular}{|c|c|c|c|c|c|c|c|c|}
\hline & & \multicolumn{2}{|c|}{$\begin{array}{c}\text { Islamic pricing for proposed } \\
\text { model }\end{array}$} & & & \multicolumn{2}{|c|}{$\begin{array}{c}\text { Conventional pricing for proposed } \\
\text { model }\end{array}$} & \\
\hline Date & Idif & $\begin{array}{c}\text { Payer } \\
\text { premium }\end{array}$ & $\begin{array}{c}\text { Receiver } \\
\text { premium }\end{array}$ & Pdif & Rdif & $\begin{array}{c}\text { Payer } \\
\text { premium }\end{array}$ & $\begin{array}{c}\text { Receiver } \\
\text { premium }\end{array}$ & Cdif \\
\hline 2016 & 15.7 & 39.37229 & 23.651506 & -0.2 & -4.7 & 39.527502 & 28.315563 & 11.2 \\
\hline 2015 & 10.2 & 49.303433 & 39.0888833 & 0.09 & -23 & 49.204757 & 62.155082 & -12 \\
\hline 2014 & 15.2 & 93.54347 & 78.2991667 & 0 & -249 & 93.542282 & 328.01863 & -234 \\
\hline 2013 & 7.97 & 78.10966 & 70.131725 & -21 & 66.7 & 99.871101 & 3.3906069 & 96.5 \\
\hline 2012 & 2.96 & 104.66002 & 101.695485 & -1.8 & 64.4 & 106.51703 & 37.32483 & 69.2 \\
\hline 2011 & 15.1 & 54.1660883 & 39.027355 & -53 & 39 & 107.74655 & 0.0170258 & 107 \\
\hline 2010 & 9.2 & 77.6496483 & 68.43349167 & -0.8 & 27.7 & 78.375015 & 40.760798 & 37.6 \\
\hline 2009 & 3.3 & 65.9217183 & 62.605095 & -5.2 & -21 & 71.11687 & 83.504082 & -12 \\
\hline 2008 & 3.9 & 90.2441667 & 86.375265 & 1.7 & -368 & 88.567 & 454.40078 & -365 \\
\hline 2007 & 10.3 & 73.4005233 & 63.123033 & -0.4 & 49.8 & 73.8333 & 13.277213 & 60.5 \\
\hline 2006 & 2.9 & 54.3606767 & 51.50799167 & -4.6 & 52.7 & 59.007058 & 1.2004941 & 57.8 \\
\hline
\end{tabular}

Note: Idif: different between Islamic payer premium and Receiver premium (payer premium -Receiver premium). Cdif: different between conventional payer premium and Receiver premium (payer premium -Receiver premium). Pdif: different between Islamic payer premium and conventional payer premium (Islamic payer premium-conventional payer premium). Rdif: different between Islamic receiver premium and conventional receiver premium, (Islamic receiver premium-conventional receiver premium)

The premium results in table 4 are the key to understanding the effectiveness of the development of Black (1976) model to make it Sharī'ah compliant. According to table 4, the premiums for Islamic commodity swaption for both parties are approximated with small difference between them around $\$ 3$ to $\$ 15$. This is due to the relatively close prices for the premiums for both payer wa'd on commodity swap and receiver wa'd on commodity swap because the rate of return on triple A suku $k$ is not affected by the financial crises of 2008. In addition, the arbitrage has an advantage of triple-A that has the smallest risk default and is based on an underlying asset $s u k \bar{u} k$ which perceive the prices from fluctuation. The Idif difference is positive if the payer premium is higher than the receiver premium. A buyer of the Islamic payer premium must pay around $\$ 3$ to $\$ 15$ more than Islamic receiver premium. The cheapest Islamic payer premium is $\$ 39$ and the most expensive is $\$ 104$. However, the Islamic receiver premium is cheaper than Islamic payer premium with range of $\$ 23.6$ and $\$ 101.6$. In contrast, for the conventional commodity swaption there is a big fluctuation between the payer premium and receiver premium which is illustrated by the Cdif field which shows that $\$ 107$ is the highest positive difference with regard to the payer and $\$ 365$ is the highest negative difference, which is considered positive for the receiver premium. Cdif difference is due to the fluctuation of the premium prices for both parties, with the cheapest payer premium being $\$ 39$ and $\$ 28$ in receiver premium. The highest price is $\$ 107.7$ for payer premium and $\$ 454$ for receiver premium. Fluctuation of prices in conventional commodity swaption between payer and receiver premium is affected by the LIBOR rate which reached abnormally high rates during the financial crisis of 2008, that exceeded 5\%. Arbitrage opportunity arises if the interest rate is not affected in the option price (Hou \& Skeie, 2014 , p. 4). This abnormal rate during the crises period and the arbitrage are reflected on the payer prices which ranged from $\$ 39.5$ to $\$ 107.7$. The receiver price also ranged from $\$ 28$ to $\$ 454$. Therefore, the profit for both parties in conventionnal commodity swaption as well as Islamic commodity swaption was affected by the fluctuation of these prices that is illustrated in table 5 .

The profit for both parties in the Islamic and conventional commodity swaption model can be obtained by applying the payoff Black (1976) in the suggested scenarios for both parties that was explained in the methodology section. Profit for both parties in Islamic and Conventional pricing model is shown in the next table (table 5). 
Table (5) The Islamic and conventional profit for both parties

\begin{tabular}{|c|c|c|c|c|c|c|c|c|}
\hline & & \multicolumn{2}{|c|}{$\begin{array}{c}\text { Islamic Profit for Proposed } \\
\text { Model }\end{array}$} & & & \multicolumn{2}{c|}{$\begin{array}{c}\text { Conventional Profit for } \\
\text { Proposed Model }\end{array}$} & \\
\hline Date & Idif & Payer profit & Receiver profit & Pdif & Rdif & Payer profit & Receiver profit & Cdif \\
\hline 2016 & -15 & 17.43770713 & 32.9876605 & 0.1 & 4.7 & 17.318465 & 28.3236 & -11 \\
\hline 2015 & -9 & 22.81145667 & 31.72061667 & -0.1 & 23 & 22.9097433 & 8.65 & 14 \\
\hline 2014 & -15 & 35.84903 & 51.01833 & 0 & 250 & 35.850218 & -198.70113 & 234 \\
\hline 2013 & -7 & 35.5636733 & 42.68360833 & 21 & -67 & 13.80223213 & 109.42472 & -95 \\
\hline 2012 & -3 & 18.16657997 & 21.02708167 & 2 & -64 & 16.309138 & 85.3977 & -69 \\
\hline 2011 & -15 & 59.387345 & 74.52591163 & 53.6 & -39 & 5.80688 & 113.535 & -107 \\
\hline 2010 & -9 & 18.81035167 & 28.02650833 & 0.7 & -27 & 18.0849 & 55.696 & -37 \\
\hline 2009 & -3 & 21.99828167 & 25.314905 & 5.2 & 20 & 16.803 & 4.923 & 11.8 \\
\hline 2008 & -4 & 89.36332 & 93.06640497 & -1.7 & 368 & 91.040466 & -274.959 & 366 \\
\hline 2007 & -10 & 27.3194767 & 37.5803 & 1 & -50 & 26.205 & 87.426 & -61 \\
\hline 2006 & -3 & 18.6743233 & 21.52700833 & 4.6 & -50 & 14.027 & 71.8345 & -58 \\
\hline
\end{tabular}

Note: Idif: difference between Islamic payer profit and Receiver profit. Cdif: difference between conventional payer profit and Receiver profit. Pdif: difference between Islamic payer profit and conventional payer profit. Rdif: difference between Islamic receiver profit and conventional receiver profit.

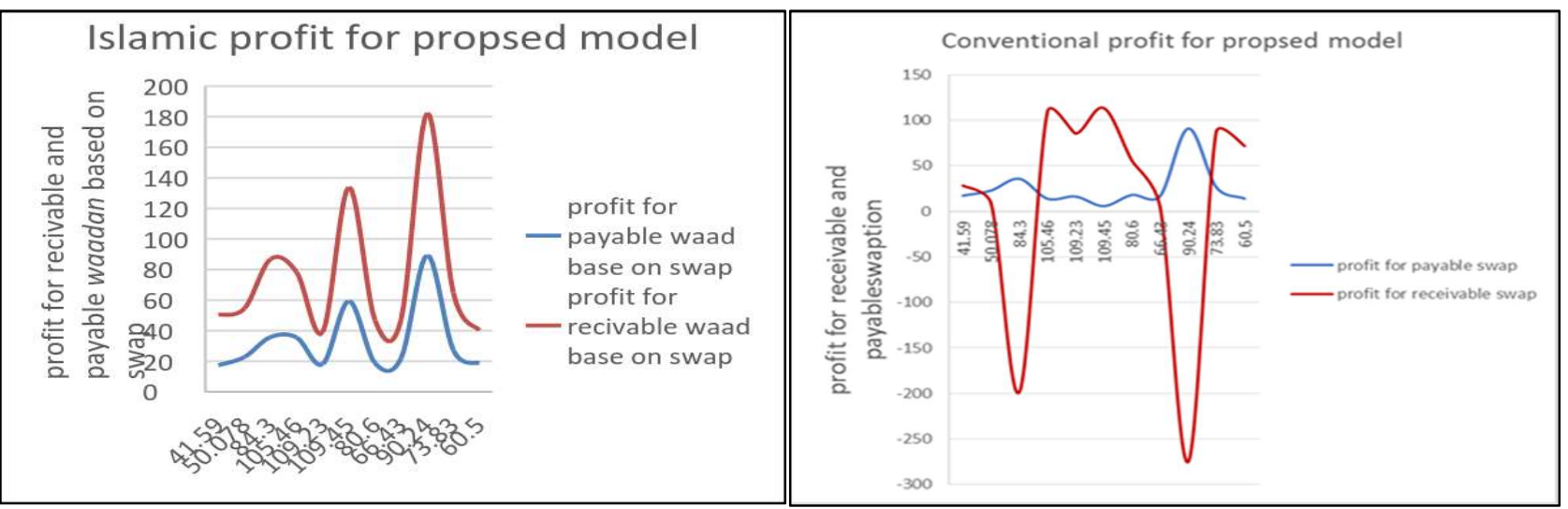

Figure (3.1) Profit for Islamic Commodity swaption

Figure (3.2) Profit for Conventional Commodity swaption

Figure $3(1,2)$ The Profit for both Parties from Islamic and Conventional Proposed Model

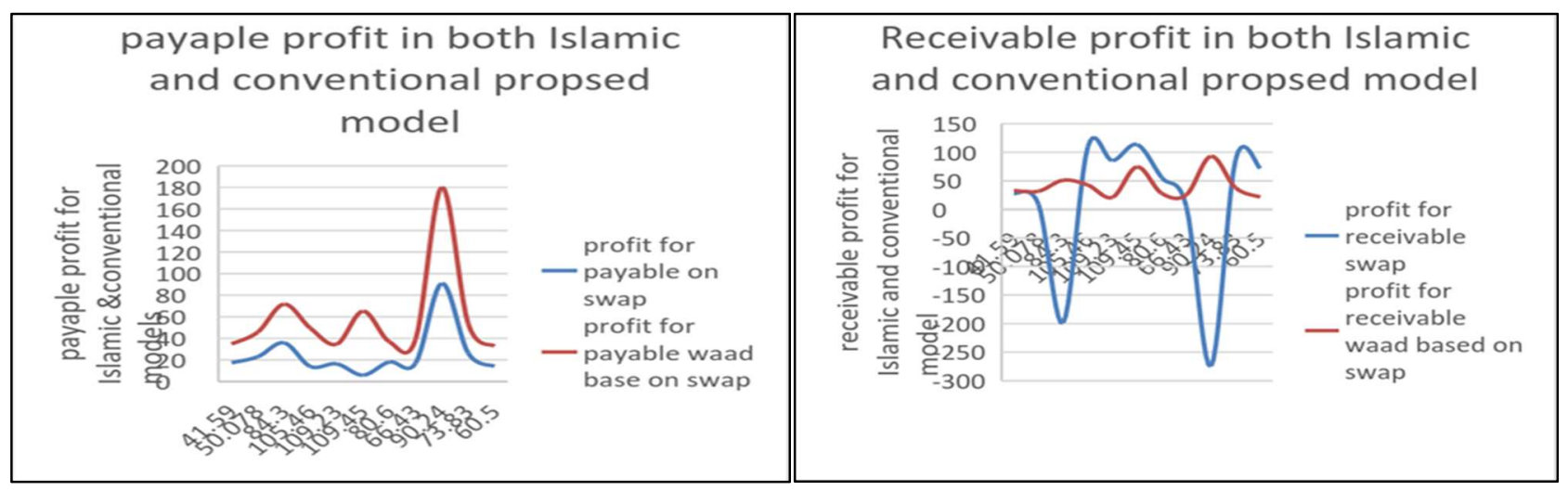

Figure (3.3) Profit for Islamic and Conventional Payer Receiver Commodity swaption
Figure (3.4) Profit for Islamic and Conventional Commodity swaption

Figure $3(3,4)$ The Profit for both Parties from Islamic and Conventional Proposed Model 
The results from table 5 and figure 3.1 show that there is no loss for both parties by using the proposed model, Islamic commodity swaption. Profits are positive for both the payer wa' $d$ on commodity swap and the receiver wa' $d$ on commodity swap. The difference between Islamic payer profit and receiver profit is clear in figure 3.1 and ascertained by the results in table 5. According to Idif, the receiver wa'd on commodity swap is more profitable than the payer wa'd on commodity swap which ranges between $\$ 3$ to $\$ 15$ during the years of the study. The maximum profit of the receiver wa' $d$ on commodity swap is $\$ 93$ and the minimum profit is $\$ 21$. The payer wa'd on commodity swap has a profitable range between $\$ 17$ and $\$ 89$. In the null model, conventional commodity swaption, the results (figure 3.2) showed that the receiver swaption suffered a loss in two different years during the period of the study which is also clearly shown in table 5 . The payer swaption has positive profits for the whole period around $\$ 5$ and $\$ 91$. Table 5 shows the loss suffered by the receiver swaption in 2008 and 2014 and the loss amount was between $\$ 198.7$ and $\$ 274.9$ which is a result of the fluctuation of the premium prices in the crisis period of 2008 due to the abnormal LIBOR rate exceeding $5 \%$. Also, in 2014 the loss is due to the fluctuation between payer swaption and receiver swaption because of the arbitrage effect (Hou \& Skeie, 2014, p. 5).

When comparing the Islamic commodity swaption model for pricing (which used the rate of return on triple A șukukk as the risk-free rate) with the conventional commodity swaption (which used LIBOR as the risk free rate) regarding parties' profit, the results show that the payer wa' $d$ on commodity swap is more profitable than the payer commodity swaption which is clear in figure 3.3. Also, table 5 asserts this that the payer wa'd on commodity swap has more profit between $\$ 1$ and $\$ 53.6$ from 2006 until 2013. However, Pdif field shows that in the last three years of the test period, there was neither a pro-fit nor a loss. For the receiver wa' $d$ on commodity swap figure 3.4 shows that the result is positive and no loss is incurred in the Islamic model unlike the conventional model which had huge losses within the period of the study. This was due to the premium fluctuation resulting from the abnormally high rate of LIBOR. The result for Islamic commodity swaption is positive in both payer wa' $d$ on commodity swap and receiver wa' $d$ on commodity swap due to the relatively close prices of the premium because the model is dependent upon the rate of return on triple A șukūk.

The rate of return on triple A șukūk was not affected by the financial crisis of 2008 and the arbitrage due to the characteristic of $s u k \bar{u} k$ that it is based on an underlying asset and has very little risk of default. However, interest rate was affected by the financial crisis of 2008 and arbitrage effect. Figure 3.4 shows that the receiver commodity swaption is more profitable than Islamic receiver commodity swaption in the middle of the test period of the study as shown by Rdif in table 5 from 2010 to 2013 .

The result from these tables and graphs allowed the study to accept the alternative hypothesis and reject the null hypothesis [which means that there is an effect on the parties' profit from the development of an Islamic pricing commodity swaption (WCS)] as Hakim also found in his study (Hakim, Hamid, \& Meera, 2016, p. 26).

Table (6) Dealer profit from the suggested Islamic model, wa 'dān on commodity swap,

\begin{tabular}{|l|l|l|l|}
\hline & \multicolumn{3}{|c|}{ Islamic profit for proposed model } \\
\hline Date & Payer profit & Tpro & Receiver profit \\
\hline 2016 & 24.15645953 & 32.8 & 8.606506167 \\
\hline 2015 & 27.26604333 & 48 & 20.732 \\
\hline 2014 & 48.46847 & 81.8 & 33.29916667 \\
\hline 2013 & 69.89966 & 132.7 & 62.779725 \\
\hline 2012 & 91.0675867 & 179 & 88.207085 \\
\hline 2011 & 50.06598833 & 85 & 34.9274217 \\
\hline 2010 & 61.79464833 & 114 & 52.57849167 \\
\hline 2009 & 44.43171833 & 85.5 & 41.115095 \\
\hline 2008 & 0.880846667 & 2 & 1.046663367 \\
\hline 2007 & 46.51385663 & 82.7 & 36.25303333 \\
\hline 2006 & 41.81567667 & 80.7 & 38.96299167 \\
\hline
\end{tabular}

Note: Tpro: total profit of the dealer from both parties 
Table 6 shows the dealer profit from the Islamic commodity swaption (WCS) that has range between $\$ 2$ and $\$ 179$ which is earned by adding the payer profit and receiver profit. Profit from each party is calculated by subtracting from the premium price the compensation for receiver wa' $d$ based on commodity swap which is represented by this formula ( $\beta_{1}-(\mathrm{Q}-$ $\left.\left.\mathrm{S}_{2}\right)\right)+\beta_{2}$. For the payer wa'd based on commodity swap the formula is the following $\beta_{1}+\left(\beta_{2}-\left(\mathrm{S}_{2}-\mathrm{Q}\right)\right)$.

\section{Third hypothesis}

Finally, the third hypothesis in this study is about testing whether the profitability value of Islamic commodity swaption (WCS) is higher than Islamic commodity option (WCO) or not. The null hypothesis is:

$\mathrm{H}_{0}$ : Islamic commodity swaption (WCS) offers the same profitability when using Islamic commodity option (WCO) for both parties.

The alternative hypothesis is:

$\mathrm{H} 3_{\mathrm{a}}$ : Islamic commodity swaption (WCS) offers more profitability than Islamic commodity options (WCO) for both parties.

To assess this hypothesis the study uses Black and Scholes (1973) model after modifying it to make it Shari'ah-compliant by replacing the risk-free rate with the rate of return on triple A sukūk to obtain both parties' premium. Black and Scholes (1973) model and Black (1976) have one important difference that can affect the result which is that in the Black and Sholes model, in normal wa'd, call option or put option, the holder can exercise only for one time at the maturity date while the Black (1976) model offers several exercise dates for different maturity lasting one year and having two-month periods. Hence, there are 6 payments per year under the swap. The following formulas are for the Black (1976) model for receiver and payer wa'd based on swap as mentioned earlier in this section.

$$
\begin{aligned}
& \mathrm{S}_{\text {payer }}=\sum_{i=1}^{M n} \mathrm{p}\left(0, T_{i}\right)\left[S_{0} N\left(d_{1}\right)-S_{k} N\left(d_{2}\right)\right] \\
& \mathrm{S}_{\text {receiver }}=\sum_{i=1}^{M n} p\left(0, T_{i}\left[S_{k} N\left(d_{2}\right)-S_{0} N\left(d_{1}\right)\right]\right.
\end{aligned}
$$

This is calculated by the following formulas:

$$
\begin{aligned}
& \mathrm{P}\left(\mathrm{T}_{0}\right)=\Sigma \mathrm{p}\left(\mathrm{T}_{0}, \mathrm{~T}_{\mathrm{i}}\right) * \max \left[(\mathrm{Q}+\mathrm{y})-\left(\mathrm{S}_{2}+\mathrm{y}\right) \mathrm{T}_{0}\right] \\
& \mathrm{C}\left(\mathrm{T}_{0}\right)=\Sigma \mathrm{p}\left(\mathrm{T}_{0}, \mathrm{~T}_{\mathrm{i}}\right) * \max \left[\left(\mathrm{S}_{2}+\mathrm{Y}\right)-(\mathrm{Q}+\mathrm{Y})\left(\mathrm{T}_{0}\right)\right] .
\end{aligned}
$$

To measure the premium of normal wa'd on commodity, using the Black and Scholes model for both parties, we use the following formulas:

$$
\begin{aligned}
& \mathrm{C}=S_{0}\left(N d_{1}\right)-e^{-r t} k\left(N d_{2}\right) \\
& \mathrm{P}=e^{-r}\left(N-d_{2}\right)-S_{0}\left(N-d_{1}\right)
\end{aligned}
$$

And the payoff for both parties after one year is calculated by:

$$
\begin{aligned}
& \mathrm{P}=\max \left[(\mathrm{Q}+\mathrm{y})-\left(\mathrm{S}_{2}+\mathrm{y}\right) \mathrm{T}_{0}\right] \\
& \mathrm{C}=\max \left[\left(\mathrm{S}_{2}+\mathrm{Y}\right)-(\mathrm{Q}+\mathrm{Y}) \mathrm{T}_{0}\right] .
\end{aligned}
$$

The research compared the Islamic proposed model, wa'dān on commodity swap, with Islamic model for wa'dān on commodity. The results are shown in the following tables, table 7 and table 8 .

The results in table 7 represent the premium for both parties in the study's proposed model. Table 7 indicates that there is a fluctuation in premium prices for both $w a^{\prime} d_{2}$ on commodity and $w a^{\prime} d_{1}$ on commodity but it is higher in $w a^{\prime} d_{l}$ ranging between \$1 and \$787. These fluctuations during the study period affect the profit for both parties. The $w a ' d_{2}$ premium based on commodity ranges between \$39 and \$109 which is more stable than $w a ' d_{1}$ on commodity. The difference between $w a^{\prime} d_{1}$ and $w a^{\prime} d_{2}$ peaked in 2008 and 2014 with a value of $\$ 749$ and $\$ 624$ respectively. This was due to the fluctuation of the prices which make the $w a ' d_{l}$ on commodity more expensive than $w a{ }^{\prime} d_{2}$. Furthermore, the fluctuation can be explained by low market expectation of oil prices going down which caused the rise of $w a{ }^{\prime} d_{l}$, put price, (García $\&$ Prokopiw, 2010, p. 1). Moreover, the fluctuation is not caused by the financial crisis period of 2008 and the arbitrage effect due to the characteristics, explained earlier, of the rate of return on triple A sukuk which is used in the Black and Sholes model. However, the difference ( $\operatorname{Idif}_{2}$ ) between the premium prices shows that $w a^{\prime} d_{2}$ on commodity is more expensive than $w a{ }^{\prime} d_{l}$ on commodity in most of the years which the study has covered. The difference between payer wa'd on commodity swap and $w a^{\prime} d_{2}$ is represented in Pdif and the difference between receiver on commodity swap and $w a ' d_{l}$ is represented by Rdif. The results show that $w a{ }^{\prime} d_{2}$ on commodity is more expensive than the payer wa'd on commodity swap with a range 
between $\$ 8$ and $\$ 52$ and that the $w a^{\prime} d_{1}$ on commodity with a range between $\$ 3$ and $\$ 701$ is more expensive than the receiver wa' $d$ on commodity swap which affect the profits for both parties. These results are logical due to the normality of the normal wa' $d$ and wa'd $\bar{a} n$ option contract which the holder can exercise only for one time at maturity date while the Black (1976) model offers several exercise dates for different maturity lasting for one year with two-month periods.

Table (7) The Result for the Premium of Islamic proposed model wa' dān on commodity swap and Islamic proposed model for wa' $d \bar{a} n$ on commodity

\begin{tabular}{|c|c|c|c|c|c|c|c|c|}
\hline \multirow[b]{2}{*}{ Date } & \multirow[b]{2}{*}{ Idif $_{1}$} & \multicolumn{2}{|c|}{$\begin{array}{l}\text { Islamic premium for wa dān on } \\
\text { commodity swap }\end{array}$} & \multirow[b]{2}{*}{ Pdif } & \multirow[b]{2}{*}{ Rdif } & \multicolumn{2}{|c|}{$\begin{array}{l}\text { Islamic premium for wa dān on } \\
\text { commodity }\end{array}$} & \multirow[b]{2}{*}{ Idif } \\
\hline & & Payer premium & $\begin{array}{l}\text { Receiver } \\
\text { premium }\end{array}$ & & & wa'd2 premium & $\begin{array}{c}\text { wa'd1 } \\
\text { premium }\end{array}$ & \\
\hline 2016 & 15 & 39.37229 & 23.651506 & -9.6 & -29 & 48.96798 & 52.54205 & -3.5 \\
\hline 2015 & 10 & 49.303433 & 39.0888833 & 14 & -38 & 35.09857 & 77.2954 & -42 \\
\hline 2014 & 15 & 93.54347 & 78.2991667 & 39.6 & -599 & 53.945 & 677.9956 & -624 \\
\hline 2013 & 8 & 78.10966 & 70.131725 & -27 & 65 & 104.911819 & 5.142809 & 99.8 \\
\hline 2012 & 3 & 104.66002 & 101.695485 & -5 & 96.5 & 109.984 & 5.142809 & 105 \\
\hline 2011 & 15 & 54.1660883 & 39.027355 & -52 & 39 & 106.9640504 & 0.05619142 & 106 \\
\hline 2010 & 9 & 77.6496483 & 68.43349167 & -18 & -8 & 95.49653 & 76.50029 & 19 \\
\hline 2009 & 3 & 65.9217183 & 62.605095 & -8 & -105 & 74.08496 & 167.61349 & -93 \\
\hline 2008 & 4 & 90.2441667 & 86.375265 & 52 & -701 & 38.8 & 787.867 & -749 \\
\hline 2007 & 10 & 73.4005233 & 63.123033 & -16 & 30 & 89.3099 & 33.14022 & 56 \\
\hline 2006 & 3 & 54.3606767 & 51.50799167 & 0 & -3 & 54.15755 & 1.61389 & 52.5 \\
\hline
\end{tabular}

Note: Idif 1 difference between premium of payer wa' $d$ on commodity swap and premium of receiver $w a{ }^{\prime} d$ on commodity swap. Idif $f_{2}$ : difference between premium of payer $w a^{\prime} d$ on commodity and premium of receiver $w a^{\prime} d$ on commodity. Pdif: difference between premium of payer $w a^{\prime} d$ on commodity swap and premium of payer $w a^{\prime} d$, on commodity. Rdif: difference between premium of receiver $w a^{\prime} d$ on commodity swap and premium of receiver $w a^{\prime} d$ on commodity.

Table (8) The Profit for two parties for wa' $d \bar{a} n$ on commodity swap and wa 'dān on commodity

\begin{tabular}{|c|c|c|c|c|c|c|c|c|}
\hline \multirow[b]{2}{*}{ Date } & \multirow[b]{2}{*}{ Idif 1} & \multicolumn{2}{|c|}{$\begin{array}{l}\text { Profit for wa dān on } \\
\text { commodity swap }\end{array}$} & \multirow[b]{2}{*}{ Pdif } & \multirow[b]{2}{*}{ Rdif } & \multicolumn{2}{|c|}{$\begin{array}{l}\text { Profit for wa } d \bar{a} n \text { on } \\
\text { commodity }\end{array}$} & \multirow[b]{2}{*}{ Idif $_{2}$} \\
\hline & & Payer profit & Receiver profit & & & $w a^{\prime} d_{2}$ profit & wa' $d_{1}$ profit & \\
\hline 2016 & -15 & 17.43770713 & 32.9876605 & 0.5 & 16 & 16.95618 & -10.03789 & 27 \\
\hline 2015 & -9 & 22.81145667 & 31.72061667 & 44 & 59 & -21.46057 & -27.6034 & 6 \\
\hline 2014 & -15 & 35.84903 & 51.01833 & 79 & 635 & -43.32584 & -584.29644 & 541 \\
\hline 2013 & -7 & 35.5636733 & 42.68360833 & 29 & -57 & 6.217341 & 100.046351 & -94 \\
\hline 2012 & -3 & 18.16657997 & 21.02708167 & 23 & -123 & -4.7732 & 144.67871 & -149 \\
\hline 2011 & -15 & 59.387345 & 74.52591163 & 62 & -30 & -2.490504 & 104.536191 & -106 \\
\hline 2010 & -9 & 18.81035167 & 28.02650833 & 17 & 24 & 1.92347 & 4.13971 & -2 \\
\hline 2009 & -3 & 21.99828167 & 25.314905 & 8 & 126 & 14.00084 & -101.04769 & 115 \\
\hline 2008 & -4 & 89.36332 & 93.06640497 & 146 & 790 & -56.3842 & -697.5018 & 641 \\
\hline 2007 & -10 & 27.3194767 & 37.5803 & 8.5 & -3.6 & 18.83081 & 41.20058 & -22 \\
\hline 2006 & -3 & 18.6743233 & 21.52700833 & 23.7 & 23.6 & -2.16175 & 59.24191 & -61 \\
\hline
\end{tabular}

Note: Idif 1 : difference between Islamic payer profit and Receiver profit. Idif 2 : difference between $w a{ }^{\prime} d_{I}$ profit and $w a$ ' $d_{2}$ profit. Pdif: difference between Islamic payer profit and $w a^{\prime} d_{2}$, call option, Rdif: difference between Islamic receiver profit and $w a{ }^{\prime} d_{l}$ profit, put option. 


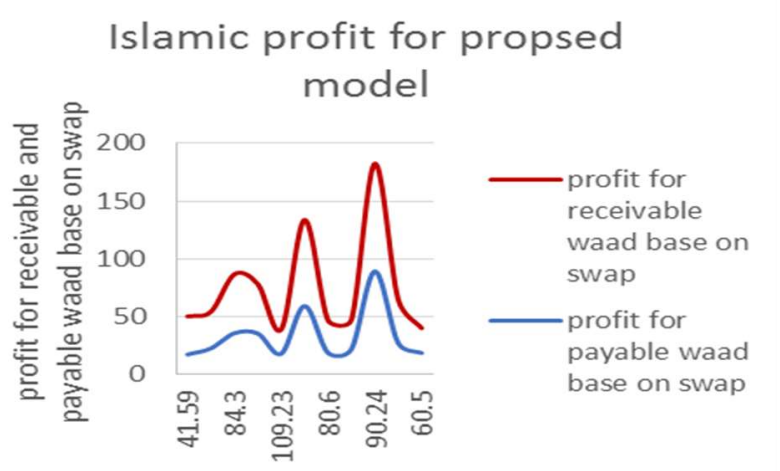

Figure (4.1) profit for Islamic commodity swaption

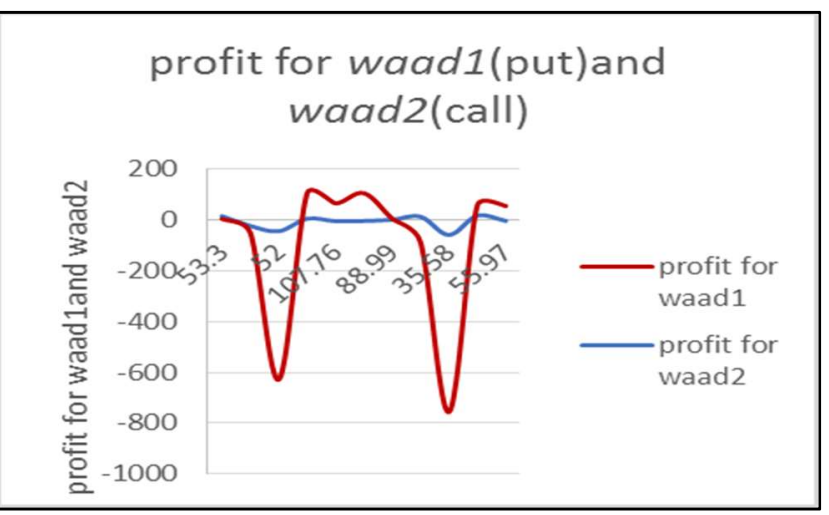

Figure (4.2) profit for wa' $d \bar{a} n$ on commodity

Figure $4(1,2)$ : the profit for both parties in $w a$ 'dān on commodity swap and in wa'dān on commodity

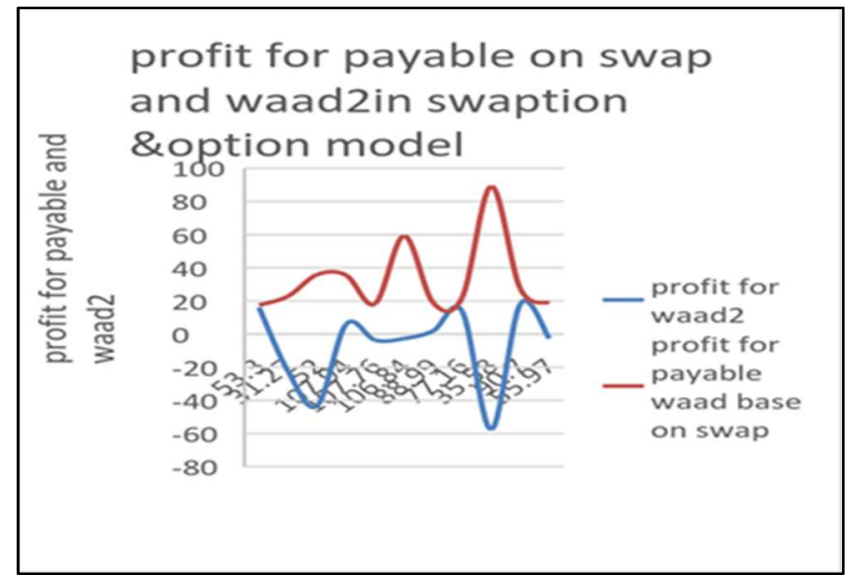

Figure (4.3) profit for payer on swap and wa' $d_{2}$

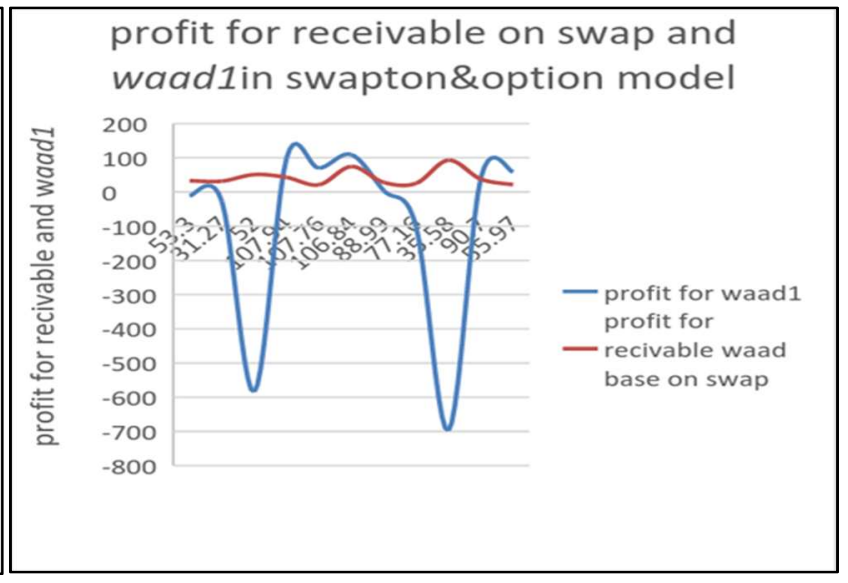

Figure (4.4) profit for receiver on swap and wa' $d_{1}$

Figure $4(3,4)$ the profit for both parties in wa' $d \bar{a} n$ on commodity swap and in wa'dān on commodity

The profit for the WCS is already clarified in table 5 . Figure 4.2 shows that WCO is more profitable for $w a d_{2}$, call option, than wa'd $d_{1}$, put option, which suffers huge losses during the test period. Table 8 indicates that the enormous losses of $w a^{\prime} d_{l}$ happened in 2008 and 2014 with losses amounting to $\$ 697.5$ and $\$ 584$ respectively. These losses were caused by the premium prices fluctuation that happened within the study period. The profit that the holder of $w a d_{1}$ earned during the period of the study is between $\$ 4$ and $\$ 144$. The holder of $w a{ }^{\prime} d_{2}$ earned between $\$ 6$ and $\$ 16$. However, the holder of $w a{ }^{\prime} d_{2}$ had losses that ranged between $\$ 2$ and $\$ 56$ while the holder of $w a^{\prime} d_{l}$ had losses that ranged between $\$ 10$ and $\$ 697$. In table 8 the $\mathrm{Idif}_{2}$ indicates that the greatest difference between $w a^{\prime} d_{2}$ and $w a^{\prime} d_{l}$ is in 2008 and
2014 with the value being $\$ 641$ and $\$ 541$ respectively where $w^{\prime}{ }^{\prime} d_{2}$ was more profitable than $w a^{\prime} d_{l}$. However, in 2011, 2012 and 2013 with values of $\$ 106, \$ 149$ and $\$ 94$ respectively, wa $d_{l}$ was more profitable than $w a ' d_{2}$. Profits in these years can be explained by the fluctuation of the premium prices due to low market expectation of oil prices meaning that the $w a$ ' $d_{l}$, put prices rose. On the other hand, $w a^{\prime} d_{2}$, call prices rose when there was a high market expectation of oil prices (García \& Prokopiw, 2010, p. 1). When comparing the proposed model of the study with wa'dān on commodity, figure 4.3 shows that the profit for payer wa' $d$ on commodity swap is more profitable than $w a^{\prime} d_{2}$ due to the positive profit that the payer wa'd on commodity swap earned without any loss. Table 8 reveals that the profits of 
the payer ranged from $\$ 17$ to $\$ 89$ without any loss. The receiver $w a$ ' $d$ on commodity swap is more stable than the $w a{ }^{\prime} d_{l}$. This is clear by observing figure 4.4 that reveals that the receiver wa' $d$ on commodity swap has positive profit without any loss and slightly less than $w a^{\prime} d_{l}$. Table 8 indicates that the profit range for the receiver wa' $d$ on commodity swap is between the \$21 and \$93. These results are due to the special characteristic in wa'dān on commodity swap that permit the holder to swap for several times in one year with two-month intervals while wa'dān on commodity is exercised only one time at maturity date.

Therefore, the data above, as presented in the tables and figures, indicates that the study must reject the null hypothesis $\mathrm{H} 3_{0}$ and accept the alternative hypothesis $\mathrm{H}_{3}$ at that Islamic commodity swaption (WCS) offers more profitability than commodity options (WCO) for both parties. The proposed model provides the holder with positive effect for wa'dān on swap more than what is offered in normal wa' $d \bar{a} n$ due to the special characteristic in wa'dān on swap that permit the holder to swap for several times in one year.

\subsection{Monte Carlo simulation}

Monte Carlo Option Price is a method to calculate the value of an option with multiple sources of uncertainties and random features, such as changing interest rates, stock prices or exchange rates, etc. ( $\mathrm{Lu}, 2011$, p. 1). In this study, RStudio software is used to easily create a sequence of a random number indicating the uncertainties that can occur in the proposed model prices. For comparing purpose, the study examines the accuracy of Black-Scholes and Black model prices by comparing them with Monte Carlo price. The following two formulas are for the Monte Carlo pricing model, which generate random numbers to predict the result and call price respectively.

$$
\begin{gathered}
S_{\mathrm{n}+1}^{K}=S n^{(k)}+\mathrm{r} S n^{(k)} \Delta \mathrm{t}+\sigma S n^{(k)} \mathrm{en}+1 \sqrt{t}, \quad S^{K}{ }_{0}=\mathrm{S} \\
\mathrm{c}(\mathrm{s})=(1+\mathrm{r} \Delta \mathrm{t})^{-N}\left\{\left(\frac{1}{m} \sum_{i=1}^{m} \int(s N)^{(k)}\right\}\right.
\end{gathered}
$$

Now we insert all data to the Monte Carlo model to check the accuracy of our results by comparing the Monte Carlo approximation with the exact values computed from the Black and Black Scholes models. The results are given in table 9.

\begin{tabular}{|c|c|c|c|c|c|c|}
\hline \multirow[t]{2}{*}{ Product type } & \multicolumn{2}{|c|}{$\begin{array}{c}\text { MCE (10.000) for each } \\
1000\end{array}$} & \multicolumn{2}{|c|}{ Black (1976) } & \multicolumn{2}{|c|}{$\begin{array}{c}\text { Black \& Scholes } \\
\text { (1973) }\end{array}$} \\
\hline & Call & Put & Call & Put & Call & Put \\
\hline Islamic commodity swaption & 70.96967 & 62.1385 & 70.978 & 62.1348 & & \\
\hline Conventional commodity swaption & 78.81121 & 95.30912 & 78.81222 & 95.2877 & . & 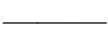 \\
\hline Islamic commodity option & 73.78957 & 174.54 & & & $\begin{array}{l}73.792 \\
76813\end{array}$ & $\begin{array}{c}174.47 \\
595\end{array}$ \\
\hline
\end{tabular}

Table (9) Comparing the accuracy of Black and Black Scholes model with Monte Carlo simulation

Note: MCE is Monte Carlo estimates

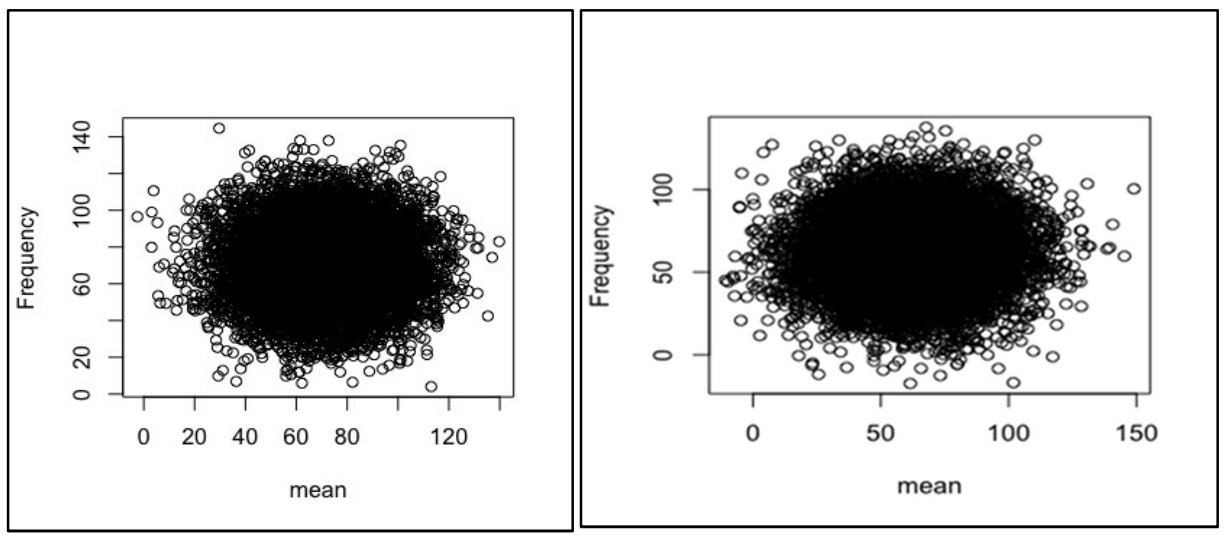

Figure (5) $w a^{\prime} d_{2}$ (call) and $w a^{\prime} d_{1}$ (put) simulation for Islamic commodity swaption respectively 


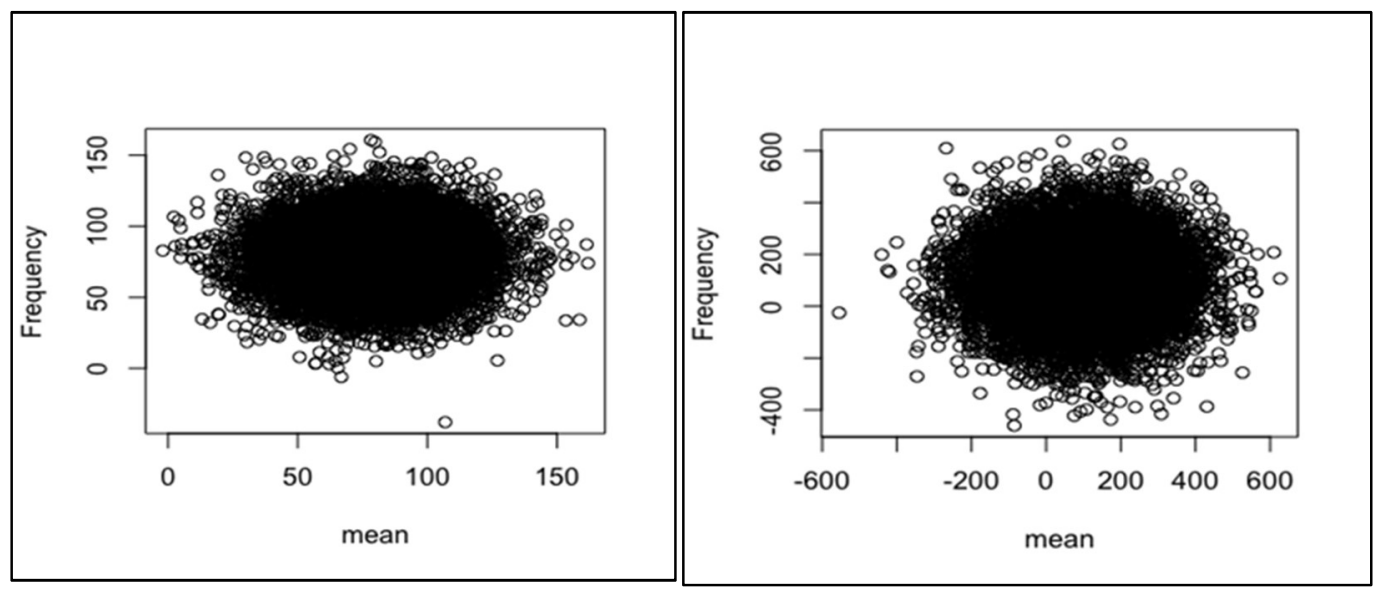

Figure (6) call and put for Conventional commodity swaption respectively

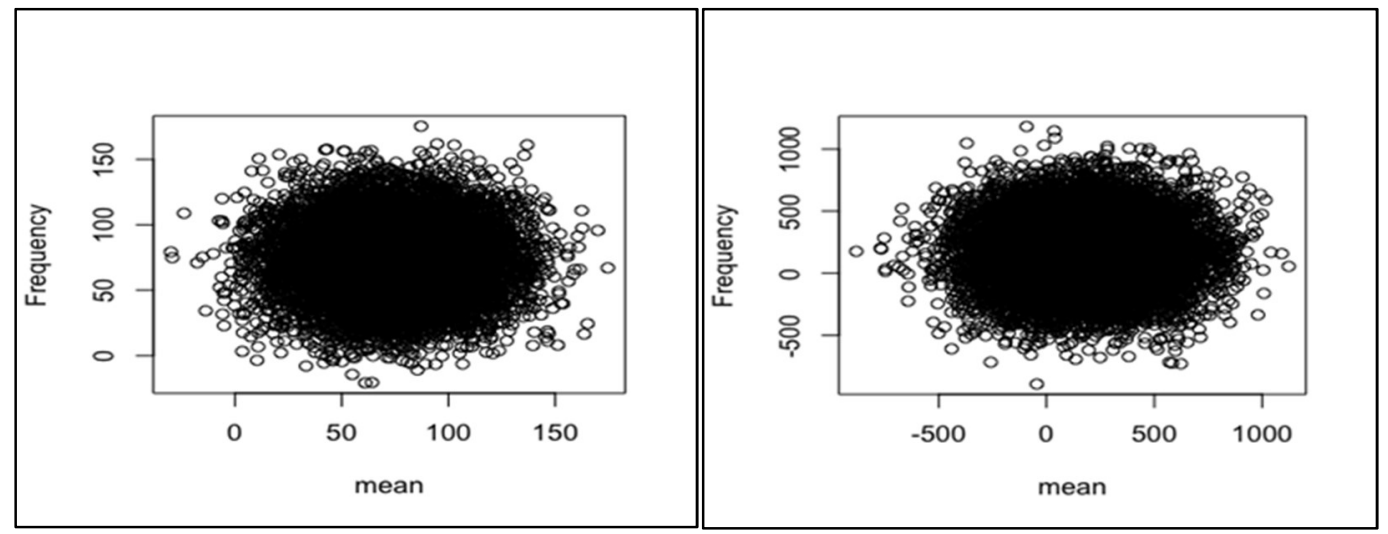

Figure (7) $w a$ ' $d_{2}$ (call) and $w a d_{1}$ (put) for Islamic commodity option respectively

Figure 5 shows the option price as well as its mean return from simulation and it revealed that the mean price is close to the price of the Black model for the proposed model of the study which is 70.969 and 62.1385 for payer wa'd based on swap and receiver wa' $d$ based on swap respectively. These numbers are very close to the Islamic Black model prices for the proposed model that are indicated in table 9 which are 70.978 and 62.1348 for payer and receiver respectively. These results were obtained after running 10,000 iterations for each 1000 which are represented in the figures in the y axis (frequency). Figure 6 shows the mean return of con-ventional commodity swaption as 78.811 and 95.309 for both payer swaption and receiver swaption respectively; this is very close to the Black (1976) which is found in table 9 with values of 78.812 and 95.287 for both payer and receiver respectively. Figure 7 revealed that MC (Monte Carlo), in the sim-ulation is 73.789 and 174.54 for both parties $w a^{\prime} d_{2}$, call option, and $w a^{\prime} d_{1}$, put option, respectively. In addition, these number are similar to the Islamic Black and Sholes, modified by replacing the risk-free rate with the rate of return on triple A sukukk. The prices for both parties which appear in the table are 73.792 and 174.475 for $w a^{\prime} d_{2}$ and $w a ' d_{l}$ respectively. From these result, it can be concluded that the Islamic Black model, conventional Black model and Islamic Black and Scholes results are reliable.

\section{Conclusion}

The proposed model provides risk management departments a good hedging tool for protecting the two parties against price risk. In addition, the product can be implemented to hedge many other kinds of risks such as currency risk and profit rate risk. The proposed model will improve Islamic hedging technique and fill the gap of Islamic derivatives products. This study also offers empirical evidence based on real data. 
The main limitation in this study is the lack of available literature that offer a working model for wa' $d \bar{a} n$ and apply or price it on real data. This prevented the study from comparing its result with previous work. Another limitation for the field of the study is the difference of opinion among Islamic scholars regarding the permissibility of derivatives due to the gharar that some argue is inherently included in these kinds of products if the guidelines of constructing an Islamic product are not strictly followed. The pricing formula for these products is based on interest rate or risk-free rate which is riba $\bar{a}$ in Islamic finance. Subsequently, these reasons discourage researchers from producing more work and products in this area. Thus, most researchers do not invest time and effort to investigate and eliminate the prohibited element in such products. Hence, this is a rare topic in Islamic literature.

The objective of this study were to create an innovative product for hedging purposes and pricing the proposed model in accordance to Sharīah laws; modify Black (1976) model through substituting the risk-free-rate with the rate of return on triple A șuku $k$; clarify the usefulness of Islamic commodity swaption over the Islamic commodity option; contribute and enrich the literature on practicing wa'd and wa'dān on real data; and reduce the gap currently present in the Islamic derivatives field.

The results that the study found, based on Monte Carlo simulation, positively proved that the proposed model has an intrinsic value via the amount of money that the product can protect from the loss which is determined by the payoff formula of Black model. Moreover, switching the risk-free-rate with the rate of return on triple A sukūk in the Black model has positively affected both party profit in our proposed model and proved to provide higher profits when compared to the conventional pricing model. Triple A șuku $k$ have a very low risk of default as they are based on an underlying asset which hedge the prices from fluctuation. In contrast, LIBOR is affected by recent financial crises due to the abnormally high interest rate, over $\% 5$, that led to prices fluctuation as well as the arbitrage that arises if the option prices are not affected by the interest rate (Hou \& Skeie, 2014, p. 4). Consequently, both LIBOR and triple A șukūk affect the profit for both parties. The results of this study are somewhat similar to Hakim, Hamid and Meera (2016, p. 26) regarding the efficiency of Islamic CAPM.
This research shows the effectiveness of the proposed model, WCS, over the WCO regarding the two parties' profit. Due to the special characteristic in WCS that permit the holder to swap for several times in one year with two-month periods while $\mathrm{WCO}$ is only exercised one time at maturity date.

\subsection{Recommendations for future research}

1. Hedging commodity price risk as was suggested by researchers to use wa' $d$ through muräbahah contract to hedge against commodity price risk which is the goal for the proposed model in this study, yet this study uses wa'dān (Kok, Giorgioni, \& Laws, 2014, p. 6).

2. This proposed model can be applied as a mushārakah mutanāqișah (MM) product which is a diminishing partnership that contains two separate independent wa'ds, wa'd from customers to bank to buy the shares of the asset, and wa' $d$ from bank to customers in case the customer needs early settle-ment. The two wa'ds are also used to protect the bank from default of customers and customer from price risk. Some scholars suggested the use of a third wa'd, yet the proposed model eliminates the need for the third wa'd (Zaini \& Isa, 2011, p. 39)

3. This proposed model is useful for oil hedging due to the innovation of combining the swap and Islamic option (wa'dōn) that provide both parties several benefits. First, the holder of the wa' $d$ can exercise the option many times before the maturity date. Second it increases the profit chances for each party and decreases the loss chances due to the special characteristic of this product.

The main contribution of this study is to apply the proposed model on real data and find results that helped in understanding the effectiveness of the model regarding parties' profit and hedging risk which is an important aspect in protecting Muslim wealth and fills the gap of empirical studies in the field of Islamic derivatives. Further research in this Islamic derivatives area is important and essential to develop and analyze further the results found in this study and to apply them to real assets like commodity, currency and profit rate. The more time scholars invest in this field of study the more will be the chances of solving the problems facing the Islamic derivatives field. 


\section{References}

Abdullah, Md. Faruk, \& Abdul Rahman, Asmak (2015). The Status of Muwa'adah and Wa'dan in The Syari'ah. Jurnal Fiqh, 12, 113-138.

Aboulaich, Rajae, \& Dchieche, Amina (2015). Pricing of Waad Bil Mourabaha. Asian Journal of Applied Sciences, 3(3), 527-536.

Ayub, M. (2011, December). Use of W'ad and Tawarruq for Swaps in the framework of Islamic Finance. Paper presented at the 8th International Conference on Islamic Economics and Finance, Doha, Qatar. Retrieved from: http://www.iefpedia.com/english/wpcontent/uploads/2011/12/Muhammad-Ayub.pdf.

Bashir, Fadul Abdul Karim (2016). Tatbiqat uqud altahawut fi al-masarif al-Islamiyah wa ahkamuha alShar'iyah [Applications of Hedge Contracts in Islamic Banks and their Sharia Provisions]. Majallat al-Buhuth wa al-Dirasat al-Shariyah, 45, 157-200.

Black, F. (1976). Studies of stock market volatility changes. In American Statistical Association, Proceeding of the 1976 Meeting of the Business and Economic Statistics Section (pp. 177-181). Washington DC: American Statistical Association.

Black, F., \& Scholes, M. (1973). The pricing of options and corporate liabilities. Journal of Political Economy, 81(3), 637-654.

García, A., \& Prokopiw, A. (2010). Market Expectations and Option Prices: Evidence for the Can\$/US\$ Exchange Rate (Bank of Canada Staff Discussion Paper No. 2010-2). Retrieved from: https://www. bankofcanada.ca/wp-content/uploads/2010/05/dp102.pdf

Hakim, S.A., Hamid, Z., \& Meera, A.K.M. (2016). Capital Asset Pricing Model and Pricing of Islamic Financial Instruments. Journal of King Abdulaziz University: Islamic Economics, 29(1), 21-39.

Hasan, A. (2008, February). Pengertian al-wa'ad, alwa'dan dan al-muwa'adah [The meaning of al-wa'ad, al-wa'dan and al-muwa'adah]. Paper presented at the Muzakarah Cendekiawan Syariah Nusantara, International Shariah Research Academy for Islamic Finance, Kuala Lumpur, Malaysia.

Hou, D., \& Skeie, D. (2014). LIBOR: Origins, Economics, Crisis, Scandal, and Reform (Federal Reserve Bank of New York Staff Reports, No. 667). Retrieved from: https://www.newyorkfed.org/medialibrary/media/resea $\mathrm{rch} /$ staff_reports/sr667.pdf

International Swaps and Derivatives Association (ISDA). (2013, April). Disclosure Annex for Commodity Derivative Transactions. Retrieved from: https://globalmarkets.bnpparibas.com/gm/features/docs /dfdisclosures/ISDA_Commodity_Derivatives_Disclos ure_Annex_04_2013.pdf

Kok, S.K., Giorgioni, G., \& Laws, J. (2014). Derivative products and innovation in Islamic finance: A hybrid tool for risk-sharing options. International Journal of Islamic and Middle Eastern Finance and Management, 7(3), 242-257.

Lu, B. (2011). Monte Carlo simulations and option pricing (undergraduate research paper at the Pennsylvania State University). Retrieved from: http://www.personal.psu.edu/alm24/undergrad/bingqia nMonteCarlo.pdf

Muhammad, M., Yaacob, H., \& Hasan, S. (2011). The bindingness and enforceability of a unilateral promise (wa'd): an analysis from Islamic law and legal perspectives (International Shari'ah Research Academy for Islamic Finance, Research Paper No. 30). Retrieved from: https://uaelaws.files.wordpress.com/2012/05/ bindingness-and-enforceability-of-a-unilateralpromise-wad-an-analysis-from-islamic-law-and-legalperspectives.pdf

Zaini, S.M., \& Isa, N.M. (2011). The Application of Wa'd in Islamic Banking Contract. Malaysian Accounting Review, 10(2), 27-45. 
Nahla Ghazi Al judaibi is a Master degree in Islamic finance management from Effat University. She has a Foundational Financial Accounting Certificate exam from IMA the Institute of Management Accounts. Currently, she works as a financial analyst at a logistics company.

E-mail: nahlaghazi1@gmail.com

Shabir Ahmad Hakim is a $\mathrm{PhD}$ in Business Administration with concentration in Finance from the International Islamic University Malaysia. He is the winner of 2015 Permodalan Nasional Berhad award for the best PhD student. He also has a Master of Business Administration with honors from Western Michigan University, USA. Currently, he works as Assistant Professor in Finance at Effat University Jeddah, Saudi Arabia. His research interests are in the areas of Asset Pricing, Emerging Markets, Corporate Finance, and Islamic Finance.

E-mail: shabirhakim@yahoo.com

Tahar Tayachi is a $\mathrm{PhD}$ in Finance, a researcher in Islamic finance and a professor of finance at Effat university. He is working on many topics in conventional and Islamic finance especially pricing and risk management. He has published papers on multidimensional portfolio management and risk management.

E-mail: ttayachi@effatuniversity.edu.sa 


\section{نمذجة أسعارعقود سلع المبادلة الإسلامية هلة غازي الجديبي، شبير أحمد حكيم، طاهر طياشي جامعة عفت، جلدة، المملكة العببية السعودية}

المستخلص. إن المشتقات التي تدير مخاطر السلع على مدى فترات متعددة ليست متوافقة مع

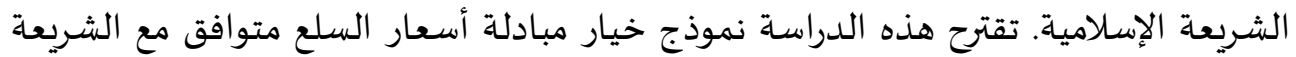
الإسلامية (نموذج الوعدين على مبادلة السلع) للتحوط من مخاطر السلع. يجمع النموذج بين وعدين على مبادلة السلع من خلال عقد المرابحة. تم استخدم نموذج بلاك (1976م) لتحديد





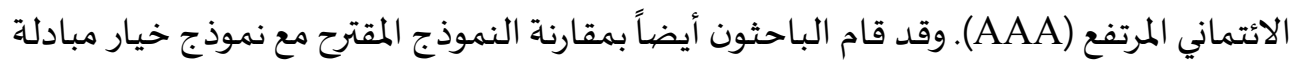



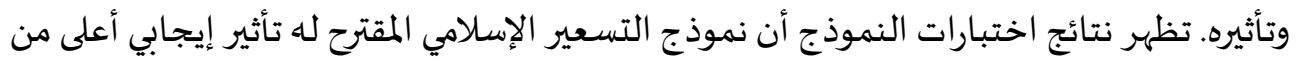

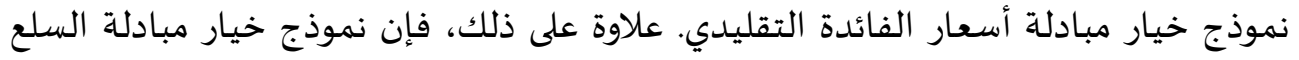
الإسلامية المقترح أكثر كفاءة من نموذج خيارات السلع الإسلامية. وقد تم إثبات موثوقية النموذج

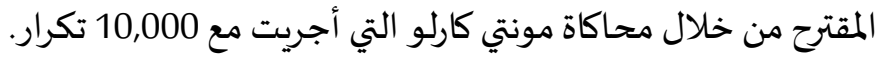
الكلمات الدَّالة: التحوط الإسلامي، خيار مبادلة السلع الإسلامياة، وعدان على مبادلة السلع. تصنيف K1, K14, L31 KAUJIE 